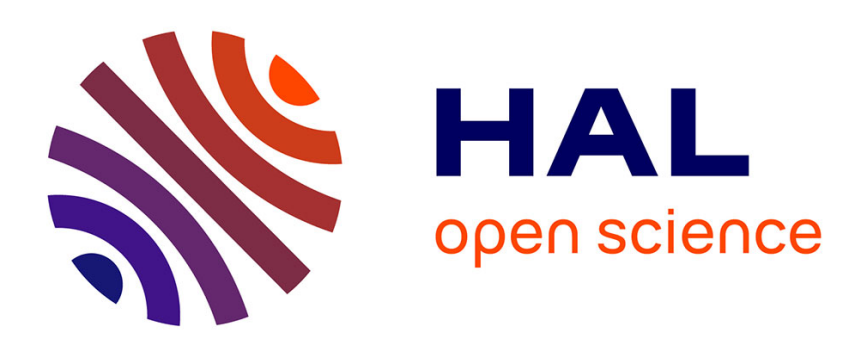

\title{
In Search of the Theatrical Unit of Meaning: Exploring Mnemonic by Simon McBurney
}

\author{
Ana Boariu
}

\section{To cite this version:}

Ana Boariu. In Search of the Theatrical Unit of Meaning: Exploring Mnemonic by Simon McBurney. Studia Universitatis Babes-Bolyai, Dramatica, 2017, 62, pp.221 - 239. 10.24193/subbdrama.2017.2.12 . hal-03205638

\section{HAL Id: hal-03205638 \\ https://hal.univ-lorraine.fr/hal-03205638}

Submitted on 22 Apr 2021

HAL is a multi-disciplinary open access archive for the deposit and dissemination of scientific research documents, whether they are published or not. The documents may come from teaching and research institutions in France or abroad, or from public or private research centers.
L'archive ouverte pluridisciplinaire $\mathbf{H A L}$, est destinée au dépôt et à la diffusion de documents scientifiques de niveau recherche, publiés ou non, émanant des établissements d'enseignement et de recherche français ou étrangers, des laboratoires publics ou privés. 


\title{
In Search of the Theatrical Unit of Meaning: Exploring Mnemonic by Simon McBurney
}

\begin{abstract}
ANA BOARIU1
Abstract $^{2}$ : The author is searching for the theatrical unit of meaning exploring the way Simon McBurney builds up the performance in Mnemonic, a Complicite Theatre production created for the 1999 Salzburg Festival. Inspired by headdriven phrase structure grammar and Chinese pictograms, the paper looks for verbs and actions that define a matrix, where each element determines the complex theatrical sign. Any change of one single sign-element causes the meaning of the whole to change.
\end{abstract}

Keywords: Simon McBurney, Mnemonic, Complicite, theatre semiotics, morpheme

\begin{abstract}
"Theatre is about the collective imagination... Everything I use on-stage is driven by the subject matter and what you might call the text - but that text can be anything, from a fragment of movement or music to something you see on a TV."
\end{abstract}

Simon Mcburney

The beginning of the performance: A few objects and, suddenly, a world is born. How? When we watch a performance, do we understand it only through emotions or do we perceive it as another kind of language? Can we analyse it from the viewpoint of the signs used, and, if so, we should then ask ourselves: What communication code is used? What kind of signs are present? How can we understand the signs paradigmatically

1. Université de Lorraine, Metz, France; Faculty of Theatre and Television, Babeș-Bolyai University, Cluj-Napoca, Romania. ana.boariu@gmail.com.

2. Translated into English by Camelia Oana 
and sintagmatically, as they appear simultaneously and successively? How is the meaning of the performance built? Can we identify one unit of meaning in theatre, as there is one in spoken languages? What would this be? The question of the theatrical unit of meaning is a very debated one and several researchers, among which Anne Ubersfeld ${ }^{3}$, deny its existence or, at least, the capacity of a theatrical unit of meaning to function similar to a morpheme in natural languages. We will discuss here, from a semiotic point of view, a production of Complicite Theatre, Mnemonic, a performance created in 1999 for the Salzburg Festival, later played at Riverside Studios, London, after a two-year long tour in Europe ${ }^{4}$. The scope is to see how signs function, how minimal units of meaning are built through a complex sign and how this complex sign can switch meanings, when only one component of it is changed, through the permanent re-semantisation of objects on stage.

\section{Mnemonic}

(Original) cast: Katrin Cartlidge, Simon McBurney, Tim McMullan, Eric Mallett, Kostas Philippoglou, Catherine Schaub Abkarian, and Daniel Wahl

Set Design: Michael Levine

Lighting Design: Paul Anderson

Sound Design: Christopher Shuff

Director: Simon McBurney

Duration: 2 hours, no intermission

\section{Just a Chair}

As indicated in the stage directions in the printed version, the performance begins with an empty stage, on which there is a chair. Simon enters the proscenium - and Simon is not the name of a character, but the very author, director, and co-founder of Complicite ${ }^{5}$. McBurney asks the audience to turn off their phones and introduces the theme of the performance. The author-

3. Anne Ubersfeld, Lire Le Théâtre (Paris: Editions Sociales, 1978).

4. Author has seen the performance during the European tour, at Bobigny, in 2001.

5. Complicite is a British group founded in 1983 by three former students of the Paris international school led by Jacque Lecoq, i.e. Simon McBurney, Annabel Arden and Marcello Magni. At the beginning, their performances were based on scripts written by McBurney, such as A minute too late (1984), A disappearing number (2007) or Mnemonic (1999), but also on classical texts, like The Master and Margarita (2011/12), Endgame (2009), Measure for Measure (2004), The Chairs (1997). http://www.complicite.org/ 
director gives a short speech on memory, in which scientific information intertwines with anecdotic details, everything connects, or rather does not connect, just like memories, he jumps from one thing to the other and ends up presenting the chair on stage. It is not just a chair: it is the chair that the director inherited from his father, a chair he used in a previous performance, The Chairs. The author invests the chair with an emotional charge, shares personal memories with the audience, individualizing the object and granting it an identity. Later on, this information will help spectators perceive the chair as a sign. A sign of the absent, who has left, and, at the same time, a sign of the expected, who isn't coming, a presence-absence. Later on, when scientists present their theories and point towards the empty chair as if Ötzi were there, the semantic charge of the object not only turns it into an indexical sign for the iceman. It becomes a symbolic sign of the presence-absence. Through this chair, the iceman who lived 5,000 years ago can also be identified with the absent father, who will never come back. At the same time, the empty chair is waiting to be occupied, it calls for a presence. The expectation is finally met when Simon-Virgil "lends his body" to signify the iceman, becoming a sign by resemblance, an icon of the perfectly preserved mummy studied by the scientists. And which they cannot know.

Finally, all the actors become Ötzi: one by one, they lie on the table, freeze, are exposed, the previous gets up, joins those walking, projected like shadows on the wall behind the stage, a wave that propagates and returns. The people walk. They each stop for a second, lying on the table in Ötzi's position, then start walking again. Repetitively. Once again. Once more. For the last time.

\section{The Sleeping Mask and the Leaf in the Plastic Bag}

Let's go back to the director's speech at the beginning of the performance ${ }^{6}$. Entering the proscenium and starting a dialogue with the audience, Simon McBurney engages the spectators by asking them to take the plastic bag they found on their chairs, to put on the "sleeping mask" (similar to the one you receive in a plane), to hold the leaf in their hands, and to try and feel its

6. Simon McBurney: in an interview for Studio 360, the actor recites the monologue at the beginning of the play again. You realize it sounds very realistic, not at all like a monologue - you actually have the feeling that it is the beginning of a conference and that the speaker is a passionate scientist. 
ribs. The "sleeping mask" is just a scarf, the leaf is just a leaf. Everyone is invited to go back in time, imagine they are children on a beach, their parents at their side, their grandparents behind them. They are asked to imagine all their ancestors, one by one, to the most distant. To feel the ribs of the leaf and compare them to the lines of a family tree. To watch the lines of ancestors come down to each of us from the depths of time.

After the chair, the leaf is the second object invested by McBurney as a symbolic sign, leaf-family tree; it is not abstract, but a very concrete symbolist sign for spectators, emotionally charged with the memory of their own parents, grandparents, great-grandparents. In the end, the line of people succeeding one behind the other, evoked at the beginning through the leaf-sign, materializes. The mere line of actors becomes the sign of your own ancestors, succeeding like a wave, always coming. They become... us! By taking two objects and investing them with - his own and the spectators' - personal memories, McBurney invites the spectator to open up and be part of a process of signifying, remembering and imagining. For each person there, the performance that is about to take place will resemble a memory process like a game of imagination.

SIMON: Modern theories of memory evolve around the idea of fragmentation. Different elements are, apparently, stored in different areas of the brain. And it is not so much the cells that are important in the act of memory, but the connection between the cells, the synapses, the synaptic connections. And these connections are being made and remade. Constantly. (...) Anyway, our job, the job of remembering is essentially not only an act of retrieval but a creative thing, it happens in the moment, it's an act, an act... of the imagination. ${ }^{7}$

Back then, and even today, it is striking to use a direct speech at the beginning of the performance, held by the leading actor (who also happens to be the author and director), which, throughout the performance, blends with the cast's stunning cohesion, with an exceptionally qualitative impro based on physical actions, with a power of suggestion based on just a couple of props and set elements and with an apt use of light, sound and video projections to tell the story. The theme of the performance - as announced by Simon McBurney - is memory and identity; a feeling of

7. Simon McBurney, Mnemonic (London-New York-Sydney: Bloomsbury Publishing, 2014), 15. 
uncertainty connects the two, by the impossibility to determine one or the other. The only real thing left is imagination, theatre. Watching the performance, the audience perceived it as a wonderful speech about the meaning of theatre: a fusion of memory and imagination, with the complicity of the spectator. Talking about the meetings with the audience after the performances in the European tour, McBurney states:

It is like this everywhere: outpourings of individual stories provoked by the 'memory journey' on which we take the audience. I remember that was one of the ways in which we made the show in the first place, going on our own memory journeys. ${ }^{8}$

What is Mnemonic about? Two main narrative threads intertwine, connected by the story of Virgil (Simon McBurney), the main character, a distant witness of the two stories. One night when he is alone in his flat, Virgil telephonically finds out about the drama that Alice, his fiancée, is going through while in Russia, where she is looking for her father, whom she thought dead. The same night, the TV shows the heated debate of the scientific community trying to identify the iceman, Ötzi, an intact mummy found in the Alps in 1991, at the border between Austria and Italy. The two parallel stories begin with an attempt to discover the identity of a lost person, starting from some remains, some signs, which can be interpreted in very different ways. One of the searches is intimate and personal, while the other is public and scientific, and gradually becomes metaphorical. The theatrical discourse combines the plan of the emotional speech with that of objective-scientific rhetoric, but eventually neither of the two, no matter how hard they try to retrieve the memory, can truly determine the identity of the other, of the hero. Or ours.

In "Performing Europe: Identity Formation for a 'New' Europe", Janelle Reinelt identifies the way in which the theme is reflected in the stylistics of the performance, where:

The transformation of objects and bodies is central to the idea that we humans carry the past concretely within our container-selves, in our brains, our postures, our nakedness. (McBurney's body is his, Virgil's,

8. Kurt Andersen, "Actor Simon McBurney on Memory" (Studio 360, 2001), http://www.wnyc.org/story/150603-actor-simon-mcburney-memory/. 
and the Iceman's, but the more arresting substitution is a chair which becomes McBurney's grandfather, a chair from the group's previous production of Ionesco's The Chairs, and the body of the Iceman under examination and exhibition.) ${ }^{9}$

The permanent re-semanticization of objects is a central element of the show. Subtly and progressively, it goes from iconic signs - the chair is a chair, whether in a conference hall or in a tram - to symbolic signs, passing through indexical signs - a mere capsized object indicating an obstacle, which, read in the paradigmatic plan alongside other signs, can be understood as a rock climbed by the mountaineers who find Ötzi. Anne Ubersfeld says, as quoted by Miruna Runcan:

Any theatrical sign, even if it is only marginally indexical and purely iconic, can be involved in an operation we call re-semanticization: any sign, even one created by accident, functions as a question asked of the spectator. ${ }^{10}$

The chair - the first object-sign of the performance, will be permanently re-semanticized, defining time and space (always imaginary). The actors grab some chairs, place them in a row, facing the audience, and suddenly become scientists holding a conference; they line them up single file, one behind the other, wobble while seating and become simple travellers in a tram. And the same chairs, turned over, next to the table, which the actors climb, dressed as mountaineers, become the dangerous cliffs on a mountain. Lights and sounds help them create the space and time, but, first and foremost, they are helped by the complicity between actors and spectators, who have to follow them and to accept the sign's permanent re-semanticization. Objects always become a new thing, through the way in which actors use them. They play with them like a child plays with a piece of wood. And actually, in the main character's imagination, everything happens in a flat where an emotionally wrecked man spends a night alone watching TV.

9. Jannette G. Reinelt, "Performing Europe: Identity Formation for a 'New' Europe," Theatre Journal 53, no. 3 (2001): 375.

10. Miruna Runcan, Pentru O Semiotică a Spectacolului Teatral (Cluj-Napoca: Editura Dacia, 2005), 68. 


\section{Blackout. The Actor Becomes a Character. The Stage Becomes a Flat}

The performance per se, a game of imagination, begins with a blackout. The lights go out, which the spectators should not even truly perceive, as their eyes are covered with the scarf. The voice of Simon, who was just talking on the microphone, goes on - this time recorded - as he makes the speech about memory. He asks the spectators to remove the scarves. Simon, now Virgil, is a spectator whose phone is ringing; he picks up, goes up on stage... and the stage becomes his world.

The third major stage of "visible" semanticization happens when Simon the actor-director becomes the character Virgil and - during a conversation turns the stage into his own apartment. Space and time are first and foremost instituted through the character's words. To begin with, he describes the real space and time, i.e. that of the theatre he is in: Simon-Virgil starts by telling his friend that he has to exit the hall to talk to him; he came to the theatre hoping to see something interesting, but he is watching a show that began with a conference and an odd scene, where the spectators' eyes were covered and they were told to remember their childhood...

Virgil goes up on stage. He tells his friend he got home. It's evening. The space of his flat is drawn up around him before our eyes: a bed, a sink, a table and a TV set are brought in. Lights and a transparent plastic curtain isolate the bedroom.

\section{Types of Discourse. Linguistic Functions}

In Mnemonic, the subtlety of the author-director consists of playing with several types of discourse, using several types of signs and placing one function of the linguistic discourse or the other at the forefront. According to Jakobson's general schema ${ }^{11}$, six elements constitute the message, i.e. the sender and the receiver, the message is sent through a code, into a context and requires a contact between the sender and the receiver. The fundamental linguistic functions occur by placing the accent on one or the other of the six elements. In Mnemonic, the surprising thing is that, instead of being engaged into a poetic world, the audience seems to be watching a conference. The first text seems to be highlighting the context, thus first emphasizing the referential function. At the same time, the end of the monologue, when

11. Roman Jakobson, "Linguistics and Poetics," in Style in Language., ed. Sebeok Thomas (Cambridge MA: MIT Press, 1960). 
Simon makes the audience participate, highlighting the contact between the sender and the receiver, the actor and the audience, emphasizes the phatic function and then immediately the conative function. The actor asks the spectator to participate. The second scene, when the set is constituted under the eyes of the spectator, and when the accent falls on the code, the metalinguistic function becomes fundamental. Almost throughout the entire show, each change of set, the way in which objects are visibly re-semanticized highlights the metalinguistic function, creating a rhythm and permanently rousing the audience's imagination. Last but not least, the emotive and the poetic function are also used in the discourse of the performance.

The poetic function is evident when the accent is placed on the message. As the show unfolds, we notice that the referential function fades away gradually, giving way to the poetic function. It all happens like a game - the whole performance is a game, right? - and McBurney induces this subtle shift by changing the way in which the video projection is used. At the beginning, an element characteristic of Virgil's space is the TV set. It signals that we are in a modern flat at also that it is the middle of the night. An important referent: scientific documentaries are broadcasted in the dead of night! At sound level, the TV preserves the reference to the context: the study of memory... We can see the light play in the box, even though, visually speaking, we can't clearly perceive anything from this world which constitutes the context.

The video projection returns later on. For the first time in the show, a poetic and emotional moment takes place. All evening, Virgil waited for Alice, his fiancée, to call. At the sound level, we receive lots of signals: his nocturnal talks with his friend, the messages he leaves on Alice's phone. Finally, Alice calls. She is in a phone booth, parallel to him on stage and quite close to the bed where Virgil is. Still, they are far away from each other. Alice has her back turned to him, we see her in profile. Virgil is at the front of the stage, looking in the distance, over the audience. He is almost naked, as he usually when at home, only wearing boxers and nothing else above the waist. And during this dialogue so longed by Virgil, Alice's face is projected on his chest. The projection on Simon-Virgil's chest is no longer a reference to the referential context, but draws the attention on the message itself, as it is. Touch-non-touch, proximity-distance, remembrancepresence, materiality-immateriality, body-image, this highly poetic moment simultaneously evokes all antinomic pairs. 
At the end of the performance, the use of video projections will reveal the very theme-metaphor, the man projecting himself in the past of his own species, i.e. over 5,000 years ago. This time encompassing the entire wall at the back of the stage - the show was also played in Bobigny on a huge stage, as big as the one at the Bucharest National Theatre -, the projection shows a window frame which, once again, should open outwards, to the performance's reference-universe. On the contrary, all the actors step into the light of the projector, with their iconic bodies, signs of the iceman, of the man who lived 5,000 years ago, and their bodies become a shadow projected on the window.

\section{The Problem of Minimal Unity or of Minimal Theatrical Sign}

Going back to the beginning of the performance and to the way in which the author-director makes up codes, we shall now discuss what a sign is, how it is built in theatre, remind how complex it is, and briefly stop upon the problem of minimal unit.

In a theatre performance - just like in film - the message is sent through different channels, through multiple signals, and:

signification is born from the systemic relation (intersection) of two axes, the syntagmatic axis (the horizontal succession of signs) and the paradigmatic axis (the vertical of associative relations between signs, in relations of opposition, continuity, alternating, etc. $)^{12}$

Because of this, determining a minimal unit, so that theatre is considered "a language" in itself, seems impossible. Anne Ubersfeld provides a reason for the impossibility of these units' existence, stating that, in theatre, one cannot identify phonemes, those minimal linguistic units (audible in any natural language) that, together, make up morphemes, the minimal unit of meaning. Nevertheless, Ubersfeld thinks that theatre is a language and describes its syntax using actants and the relations between them, using concepts from Greimas' semantics and Propp's narratology. This way of reading theatre seems to be tributary to European linguistic structure and to the syntax of European languages. Through the way in which we create writing, we are structured to consider that abstraction is the norm, that the connection between sign and signifier is very arbitrary, based, in natural languages, on a randomly selected sound and a sign, which in its turn, is arbitrarily chosen to represent a sound.

12. Runcan, 65. 
We have a sign for each phoneme; together, they form a morpheme, the minimal morphological unit, which can be a word in itself or not, can have a content or can be a determinant. Of course, since theatre uses different channels parallel: gestural and physical activity, movement, text, lights, scenography, costumes, music, and, in each plan, we can identify signs that work parallelly, completing or opposing each other, - a context is born, where the attempt to define morphemes seems like a useless, absurd effort. This might be so, as, if the definition of language itself is based on the experience of natural, mainly European languages, theatre can only be considered a parole at best, not a language.

However, both Tadeusz Kowzan, and Miruna Runcan try to define a semiologic unit of meaning. For the first, this equals to: "a slice containing all the signs emitted simultaneously, the duration of which equals that of the sign that lasts least." 13

Miruna Runcan completes his words, defining a possible minimal unit as that chosen by both partners involved in the discourse "based on a meaning homogeneity established between the elements, and homogeneity is set by the sign with the greatest contextual domination force related to the discourse flow." ${ }^{14}$

The problem that may arise is that, when presented via different channels, signs or signals have different durations. And drawing a line between minimal units, if they exist, would mean that both the sender, and the receiver accept and recognise it, deciding whether duration or intensity, or maybe both, are decisive in order to establish the separation criterion.

A minimal unit is absolutely necessary for the sender to structure his message, and based on this unit, if it is well structured, the receiver will find it easier to decode the message. Regardless of the different duration of the signals on different channels, it is enough that one message is significantly modified on one channel for the meaning of the entire ensemble to change. Despite the fact that there are no "constant discreet and coded fixed units", theatre "has the advantage of being able to generate, even during the communicational flow, a synchronic sequencing of sign ensembles, into meaning units equal to complex signs" ${ }^{\prime 15}$.

13. Ibid., 70 .

14. Ibid., 72-73.

15. Ibid., 73 . 


\section{Theatrical Sign}

We can understand the theatrical sign itself as a minimal unit of meaning, made up of a set of signs, which, through juxtaposition, acquire a different meaning. A change within this set changes the meaning of the whole, as we could see in the analyse of Mnemonic.

Can we think theatre similar to a language in which each written morpheme breaks down not into phonemes, but into other signs, as it often is a compound sign? Looking at a sign, you decode its components, which always represent something, until you get to a simple line. In Chinese, for example, each constituting element of a complex sign represents a very concrete object that can be touched, drawn. But together, they acquire a totally different meaning.

好 - a woman next to her son. Means: "Good".

问 - what do we see? A mouth inside an open gate. It means "to ask".

回 - and here, a mouth inside a closed gate, which means "to answer".

In theatre, a minimal unit, which makes sense, works just like a sign in Chinese writing, which, in its turn, is made up of elements that also have an independent meaning. It is true that there is no rule based on which to identify a finite number of units of meaning in theatrical language. Just as, in the past, Chinese writing was almost unsystematizable: with over 40,000 signs, whose number could increase infinitely, in theatre, new "units of meaning" can be created all the time. And when we can read a sign from one performance to the other, we think we are dealing with dead theatre.

Communication would be extremely difficult if the author of the performance would not "rely" on minimal units, which make sense, if he wouldn't somehow, more or less evidently, emphasize the border between these units. The borders may seem "fluid", if the tears are not marked well enough. Perhaps they are never perceived. They exist, just like in film. Or they should exist.

In Mnemonic, units of meaning are suggestively individualized and well marked by tears, especially at the level of sound. Analysing the first complex theatrical sign in Mnemonic, we can understand how, by changing an element within the sign, a new sense is created, different from that of its constituting parts. And at the same time, that the signals perceived on different channels, although they may be signs, lose their individual meaning and acquire a new meaning in the context, simultaneously with other signs. 


\section{Story \\ Virgil's Flat - the Minimal Unit of Meaning at the Beginning of the}

On the almost dark stage, behind a plastic curtain, we can distinguish the light coming from a TV set and the presence of a bed. Together, these become the sign of a disillusioned young man, left by his wife. The bedroom where the main character spends his days alone is signified. It is evening and he is watching TV. News about some American scientific research is on. About how we might get to find out what happened 5,000 years ago.

Despite several objects being present on stage at the same time, they do not work as independent signs, although they each mean something. Together, however, they acquire a new meaning and constitute one unit, a unit that has a meaning. If we modify anything in the above-described image, any one of the signs, the final meaning will change.

Let's play a game. We have the same elements: bed, table, TV set, light, hero, characterized through a costume and gestural activity. Let's change the character's costume: he is no longer in his boxers, but lying on the bed in a suit. There's a suitcase next to him. All the other elements stay the same, and still we're no longer in the bedroom of a single young man hit by melancholy (we'll find out later why), but we might be in a hotel. Another change regarding the costume: he might wear prison clothing or handcuffs. The situation changes radically. We will understand he is in prison. Let's suppose that the sound coming from the TV changes. Or the light. The ensemble of signals or signs reaching us via various channels, read by association, in a paradigmatic plan, only mean something together. Individually, they are nothing but set elements and props.

In Mnemonic, the actors constantly use the same objects: bed, table, chair. The TV is off. Virgil is lying on the floor. Alice is on the bed. At sound level, we can hear the loud noise of a moving train, it seems real. Nevertheless, the fact that Virgil is still in this space, but asleep, suggests that he is dreaming. The bed is, at the same time, the one in Virgil's flat, but also the one in Alice's berth. And, in reality, it is just an object-bed on a stage, the extraordinary object that does not only signify itself, but is open to being invested, through the complicity between actor and spectator, with any signification.

For it to have a meaning and to be decoded, it obviously needs what Miruna Runcan suggests and what Simon McBurney calls complicity from the spectator. A common referent must exist, through which the elements 
chosen to signify are absolutely necessary and, at the same time, enough to create a sign that is understood. Any noise, any extra element disturbs attention. Any missing element gives the sign a degree of indeterminacy.

McBurney characterizes the state he aimed at suggesting at the beginning through: "Emotionally unhappy, you can't sleep!"16

General situation: A man is alone in his flat, after his girlfriend left him. He walks around, calls his friend, can't sleep, watches TV. At a certain moment, his girlfriend calls in the middle of the night and tells him where she is and what happened to her.

The idea behind the play was to mimic this chaotic theories on memories. For example, in my flat in London I often watch TV... at three o'clock in the morning, and you get these amazing programmes about all sorts of factual staff. ${ }^{17}$

This experience, lived by the author, can only make the theatrical sign intelligible if shared by the audience. If the spectator is not part of the same world, for example coming from a quiet, isolated village where he doesn't even have a TV set, everything happening from this moment on might be completely unknown and unintelligible.

\section{Theatrical Convention and Codes}

In the case of Mnemonic, Simon McBurney chooses to announce and implement the theatrical convention at the beginning. He implements it in complicity with the spectator. He presents it in the monologue at the beginning of the performance. As mentioned before, the discourse covers several functions - referential, phatic, and metalinguistic - and announces the theme of the show: exploring the way in which memory works and defining our identity. At the same time, the spectator is invited to join the actors' imaginary game, using very few, permanently re-semanticized objects, through which stories are created; these stories overlap in the mind of a Londoner insomniac and all have to do with an identity search. In the case of Mnemonic, the set was made up of a bed, a table, some chairs, and a phone booth at a certain moment. There was nothing else on stage. And

16. Andersen, "Actor Simon McBurney on Memory."

17. Ibid. 
successively, or even parallelly, we are in Simon's bedroom, in a train or a tram in a Russian city, in a conference hall where scientists talk about Ötzi, in a dissection room, on a mountain. Everything is fragmented and fragmentary, identities changes, synapses and connections between objects are recreated. Using memory and imagination, using Virgil as a pretext, McBurney invites us to explore our identity. "Theatrical conventions will never equal to an inventory of codes used to produce and interpret the message in the continuous flow of theatrical discourse." ${ }^{\prime 18}$

In the performance, we see clothing codes, based on which we recognise social or professional categories: mountaineers, researchers, the police officer. Behaviour codes are also present: the scientists at the conference take a rigid stand, in a line on a stage, presenting their papers in front of an audience.

Making use of these socio-cultural codes, the group quickly suggests to the spectator who or where the characters are, especially as their role and location changes so quickly. Besides the two main characters played by Simon McBurney and Katerin Kartridge, the other actors do not play one character, but almost work as a whole body, improvising and, through suggestion, always recreating other situations, other groups of characters, with no distinct individualities. As mentioned above, the socio-cultural code plays an important part: a spectator who does not have the same referent as the author, who has never experienced a sleepless night in the middle of a big city, will not understand the state of the main character, the anxiety of a townsman who was left by his girlfriend, is an insomniac watching TV in the middle of the night, whose mind makes whirly connections. Stories intertwine, he recalls memories, fragments, details, impressions...

The idea behind this piece was almost like a geometrical structure. And I thought of seven different stories, essentially four. And the first line of a story is a story of a woman who goes East, looking for her past... The second story is a man going West, looking for his future, who is the Greek taxi driver who happens to have picked both myself and my girlfriend in two separate situations. The third story is almost like a vertical line, which is the story of a five thousand years old body that is discovered on the Austrian-Italian border in 1991. And the fourth story is the story that I have already mentioned, of the man who is alone in his flat, who is both heartbroken and obsessed by all sorts of ideas as to

18. Runcan, Pentru O Semiotică a Spectacolului Teatral, 65. 
what constitutes our lives. And I tried to literally fragment all the stories and then interweave them so that it mimics how our brain works. ${ }^{19}$

After bringing about, through a metalinguistic discourse, some signs (an iconic and symbolic sign as the chair, an iconic sign as himself, Simon-Virgil, and an indexical sign as the flat), the minimal units of meaning succeed. And, although we are not talking about a language, they follow certain syntax rules.

\section{On Syntax}

Regarding syntax, our normal syntactic grammatical model places the subject on the first place and then the predicate. It is not by chance that the syntax proposed by Ubersfeld, which is very functional and applied to the construction and analysis of a text, starts from the actant. But from the point of view of someone who every now and then builds a performance, a syntax based solely on actants is not very helpful. When building a performance, you start from a text, and the actants are given. If you improvise, you make them up. But still, all you have is a text. To move from text to performance, as the actors would say when passing from reading to the stage, you have to start moving it. In the syntax of a theatre performance, the verb comes first, not the noun, the predicate, not the subject, the action, not the actant. Another model, another language serving as a model might be of help.

In an ancient language - and by that, I mean another ancient language, Hebrew - sentences begin with the verb. And the rest of the words, all the other words, are formed based on the verb. If we would first try to identify not the actants in a theatre performance, but the transformations, we might find it easier to identify minimal units of meaning. And the minimal unit of meaning will be that in which a transformation can be identified, defined by a verb.

A useful mathematical matrix model might be that of a grammar whose sentences are structured through keywords, i.e. HPSG - head-driven phrase structure grammatic ${ }^{20}$. This model uses keywords ("heads") to make up matrices which in any human language determine both the syntactic form and the semantic interpretation of the sentences they appear in. An example of such a matrix for English is the one below, starting from "walk":

19. Andersen, "Actor Simon McBurney on Memory."

20. Carl Pollard and Ivan Sag, eds., Head-Driven Phrase Structure Grammar (Chicago: Chicago University Press, 1994). 


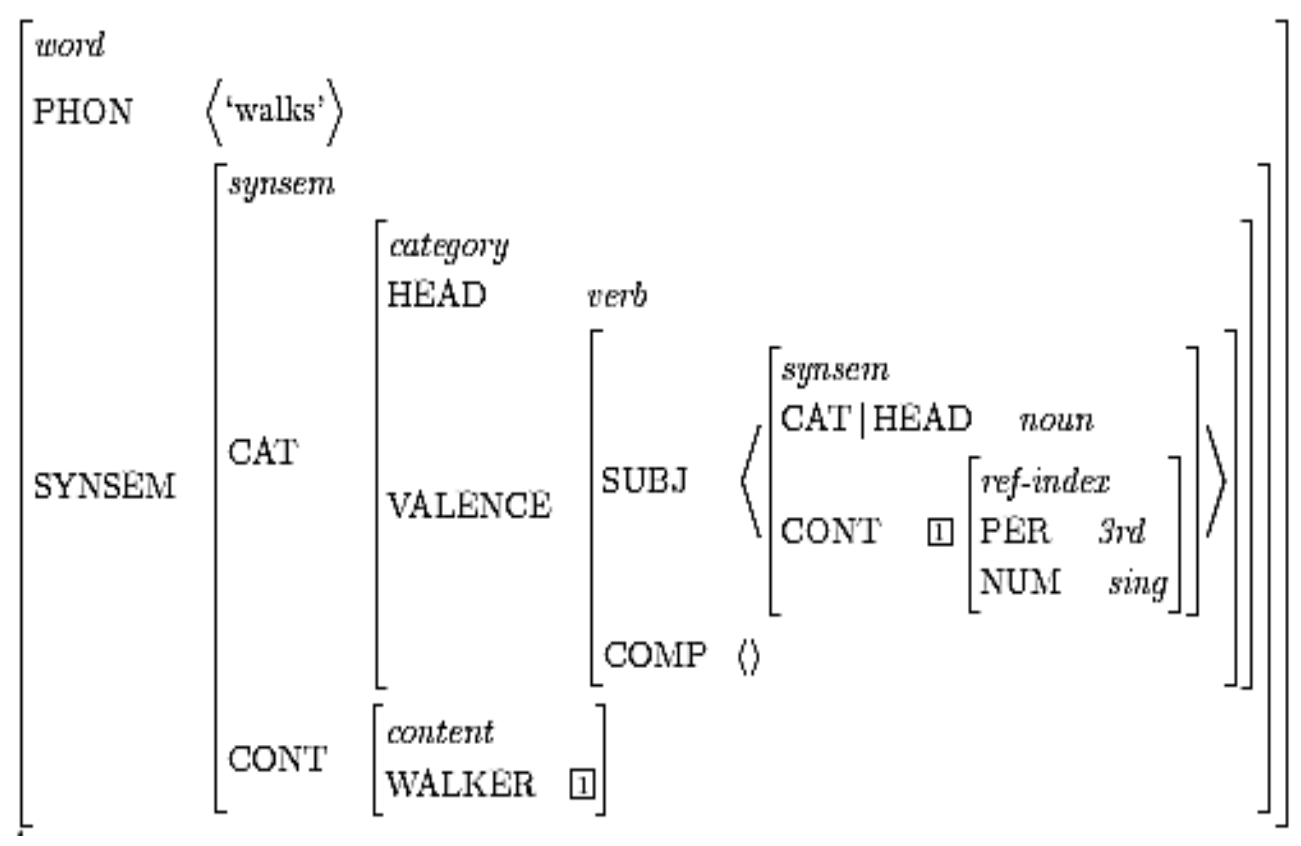

Fig. 1: Example of an attribute value matrix for "walks"

In a natural language, a verb-based matrix entails that the semantic contents and the syntactic connections required by the verb are determined: whether it requires a subject or not, whether it requires a direct object or several types of objects. This could be a model for the creation of a complex theatrical sign.

Let us go back to the theatrical sign at the beginning of Mnemonic, as described by McBurney himself: "Emotionally unhappy, you can't sleep!" Turning it into a verb-based matrix, we get two units in the first scene, the main scene built starting from the main verb "can't sleep", and a subdivision, a determinative verbal clause, "emotionally unhappy", expressed through another series of actions, which, in turn, become a sign:

Phon/Verb: can't sleep (you lie down, get up, lie down somewhere else, etc.) - insomnia 
SYNSEM: Category: HEAD: Verb: can't sleep valence: subject: Virgil: a man, single objects: where: in his flat:

signs: a bed, a table, a sink when: at night sign: a certain type of light, a night documentary on TV why: emotionally unhappy (another HEAD: verb) sign: a phone that doesn't ring (Virgil calls in vain, then a friend rings...)

The signs in this matrix, although it seems like they have an independent meaning, only exist simultaneously, like a constellation of signs, which can only create the main theatrical sign, which is also a unit of meaning, together. Mutually, when, as a spectator, you look at the stage, and the signs you are trying to decode do not make up a matrix led by a "head" that is the verb, you will have trouble finding the unit of meaning!

The first verb: "can't sleep!" And then what happens? "You climb a mountain."

These units of meaning succeed, creating a syntax by alternating rhythm and movement. Evidently, signs can also be analysed separately at the end of the performance, by channel, but their meaning would have arisen from the context. We can analyse the stylistic unit, the way in which the message is coherently sent by the artists on each channel, parallelly. Whether they use counterpoints, or agreements etc.

\section{Who Produces the Meaning? The Sender or the Receiver?}

Let's go back to the spectator and to meaning. Simon McBurney is a founder of the theatre group Complicite. He chose its name and the name expresses the way in which he understands making theatre. To him, it is not the actor who gives a meaning to the gestures and the objects on stage. Meaning is born from complicity with the spectator. 
Theatre is not even what you see on the stage. It's all about how the audience imagine. And with the idea of complicity... It's not only the idea of complicity between the people on the stage. But between the people on the stage and the people in the audience. ${ }^{21}$

McBurney keeps repeating this: "It's the audience who creates theatre. It's an imaginative act on the part of the audience. And that is theatre's appeal, that's why theatre continues." ${ }^{22}$

\section{Conclusion}

We have explored in this analyse of Mnemonic how an object on stage can be permanently invested with meaning by the complicity between actors and audience. In the same time, we saw how the performance is built by a succession of complex signs, which the audience perceives in synchronicity, but also in time. Whenever one single object is reinvested with another meaning - be it clothing, light, sound etc. - the complex sign changes its meaning. This functioning of a theatrical unit of meaning brought us to make a parallel to languages which uses pictograms, like the Chinese, where a new meaning is derived from the association of individual signs: mother and child, mouth and door brought together loose their original meaning and gain a totally new one, only through their association. Further, in order to understand how the syntax of a minimal theatrical unit can function, we turned towards the head-driven phrase structure grammar, using verbs and actions to structure all other syntax elements around them. The difficulty of perceiving minimal units of meaning in theatre, which can create a syntax and a grammar of their own, could be tributary of a way to perceive and think of language as an arbitrary association of signs and meaning, proper to the European thinking. Turning towards Eastern languages and writing systems that use pictograms might be helpful to start thinking differently about theatre and its units of meaning.

21. Andersen, "Actor Simon McBurney on Memory."

22. Carol Rocamora, "McBurney Meets Miller: The Acclaimed British Experimentalist Stretches an American Classic to New Dimensions," American Theatre 25, no. 10 (2008): 32. 


\section{References}

Andersen, Kurt. "Actor Simon McBurney on Memory." Studio 360, 2001. http://www.wnyc.org/story/150603-actor-simon-mcburney-memory/.

Dickson, Andrew. "Simon McBurney on His Theatre Group, Complicite." The Guardian, 2010. https://www.youtube.com/watch?v=SnbPAGeA6Ec .

Jakobson, Roman. "Linguistics and Poetics." In Style in Language., edited by Sebeok Thomas. Cambridge MA: MIT Press, 1960.

Matt, Trueman. "Interview: The Founders of Complicité." Financial Times, May 24, 2013.

McBurney, Simon. Mnemonic. London-New York-Sydney: Bloomsbury Publishing, 2014.

Pollard, Carl, and Ivan Sag, eds. Head-Driven Phrase Structure Grammar. Chicago: Chicago University Press, 1994.

Reinelt, Jannette G. "Performing Europe: Identity Formation for a 'New' Europe." Theatre Journal 53, no. 3 (2001).

Rocamora, Carol. "McBurney Meets Miller: The Acclaimed British Experimentalist Stretches an American Classic to New Dimensions." American Theatre 25, no. 10 (2008).

Runcan, Miruna. Pentru O Semiotică a Spectacolului Teatral. Cluj-Napoca: Editura Dacia, 2005.

Ubersfeld, Anne. Lire Le Théâtre. Paris: Editions Sociales, 1978.

Ana Boariu (Aka Anca Berlogea) is a theatre and film director born 1968. She is currently a PhD student at the Babes-Bolyai University of Cluj. After graduating theatre directing in Bucharest in 1994, and theology in 1997, she finished her master degree at the Catholic Institute in Paris in 2002, with a paper on "Memory and testimony in the Gospel of John as starting point for a theatrical representation". Theatre and Bible remains her main research area, both at a theoretical level, and in practice. But her practice is far larger, including journalism as well as television, documentary and film production. 
